\title{
Role of sugarcane bagasse and bamboo for adsorption of hydrolysed dyes from textile effluent: An overview
}

\author{
Karanjeet Kaur \\ Department of Chemistry, Guru Nanak Dev University, Amritsar-143005 (Punjab), India \\ Baljinder Kaur \\ Department of Chemistry, Guru Nanak Dev University, Amritsar-143005 (Punjab), India \\ Varinder Kaur* \\ Department of Chemistry, Guru Nanak Dev University, Amritsar-143005 (Punjab), India \\ Corresponding author . E. mail: varinder_gndu@yahoo.com

\begin{abstract}
Adsorption process is one of the best ways for removal of dyes from effluent generated from different industries. The use of adsorbent manufactured from sugarcane bagasse as well as bamboo fibre bundles, an agro squander from sugar and building industries have been reviewed as an excellent replacement for stimulated carbon sorbents for the removal of dyes from wastewater. Agricultural based adsorbents prepared from sugarcane bagasse and bamboo may be successfully used to remove the unused hydrolyzed dyes from an effluent of textile dyeing industry. These ready adsorbents may very much capable in decolorization of the textile effluent. In this review, literature of two sorbents has been compiled. The review assesses these agricultural based materials as lowcost adsorbents for the removal of hydrolysed dyes from textile effluent. The review also draws some of the basic mechanism of dye adsorption on to.
\end{abstract} \\ Abstract
}

Keywords: Adsorption, Bamboo, Cellulose, Dyes, Lignin, Sugarcane bagasse

\section{Article Info}

DOI:10.31018/jans.v10i3.1700

Received: April 5, 2018

Revised: June 10, 2018

Accepted: July 20, 2018

\section{How to Cite}

Kaur, K. et al. (2018). Role of sugarcane bagasse and bamboo for adsorption of hydrolysed dyes from Textile effluent: An overview. Journal of Applied and Natural Science, 10(3): 864 $-875$

\section{INTRODUCTION}

There are wide varieties of dyes that are being used in the textile industries and are causing water pollution by discharge of industrial effluent. Dyes are usually present in trace quantities in treated effluents of many industries (Garg et al., 2004). There are many methods for treatment of the textile effluent. These methods include chemical methods, physical methods and biological treatments. The treatments of effluent by chemical methods include oxidative processes (Cisneros et al., 2002), ozonation (Gähr, et al., 1994) photochemical treatment (Namboodri and Walsh, 1996) and by use of sodium hypochlorite (Slokar and Marechal, 1997). Physical methods for effluent treatment include adsorption by biosorbents like sawdust (Sharma et al., 2009), waste orange peel (Namasivayam et al., 1996), banana pith (Namasivayam et al., 1998), rice husk (McKAY et al., 1985) and sugarcane bagasse (Xing and Wang, 2009). The other physical methods include ion exchange (Mishra and Tripathy, 1993), Irradiation (Hosono et al., 1993), coagulation and flocculation (Zeng et al., 2014). The biological treatment includes decolonization by white-rot fungi (McMullan and Meehan, 2001). Activated carbon prepared from many substances can be used as an adsorbent. The substances that can be used to prepare activated carbon are sawdust and ricehusk (Malik , 2003), coir pith (Santhy and Selvapathy , 2006) and bamboo (Hameed et al., 2007). The manufacturing methods of these activated carbon substances again add on overall cost to cleanup methods. Therefore, cheap and eco-friendly adsorbents can be used as an alternative substitution of activated carbon for removal of dyes from wastewater. The adsorption process is one of the effective methods for removal of dyes from waste effluent (Azhar et al., 2005). There are number of low cost, easily available and effective substances which can be used as adsorbents for removal of various dyes from aqueous solution or industrial effluents. The use of sugarcane bagasse as an adsorbent, an agro waste from sugar industries has been studied as an alternative substitute for activated carbon for the removal of dyes from wastewater (Azhar et al., 2005; Saad et al., 2010). Sugarcane is a grass that is harvested for its sucrose content. Sugarcane bagasse is the fibrous residue remaining after sugarcane stalk has been crushed and the juice removed. The production of bagasse exceeds 100 million tons annually. Because of its fibrous nature, it has been used as a fuel, paper and pulp, structural materials, and agricultural uses (Han et al., 1983). Reported that bagasse contains carboxylic and hydroxyl group therefore it has been adopted as a cheap, attrac- 
Kaur, K. et al. / J. Appl. \& Nat. Sci. 10 (3): 864 - 875 (2018)

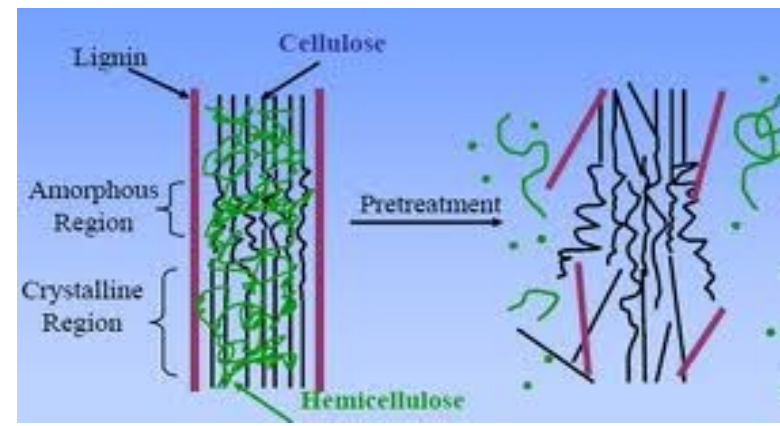

Fig. 1. Delignification process as pretreatment on biomass (Mosier et al., 2005).<smiles>CC[C@H]1O[C@H](COC)[C@@H](O)[C@H](O)[C@H](CO)[C@H]1O</smiles>

Fig. 2. Structure of cellulose (Saheb and Jog, 1999).

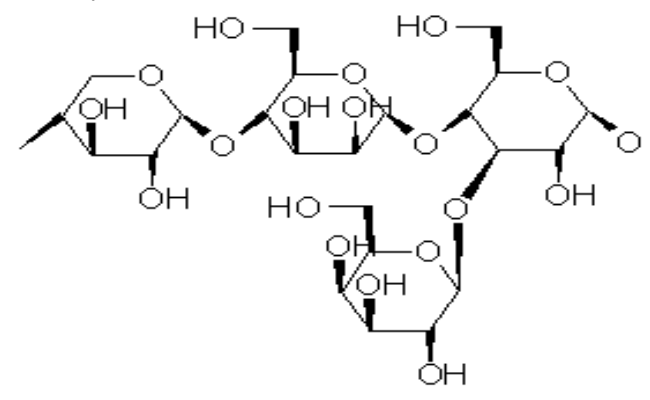

-Xylose- $ß(1,4)$ - Mannose - $ß(1,4)$ - Glucose - Alpha (1, 3) - Galactose Hemicellulose

Fig. 3. Hemicellulose (Brienzo et al., 2016).

tive and effective adsorbent for removal of dyes from wastewater (Saad et al., 2010). A number of reports have been published on sugarcane bagasse acting as an adsorbent for different dyes. These reports show that different pretreatment methods can be employed in order to make bagasse an effective adsorbent .These pretreatments act by disrupting the lignocellulosic matrix (Fig. 1.) thereby reducing the amount of lignin and hemicelluloses as well as modifying the crystalline structure of cellulose to make it more susceptible for adsorption (Silverstein et al., 2007).

Sugarcane bagasse acts as an adsorbent for many dyes present in the industrial effluent. Bam-

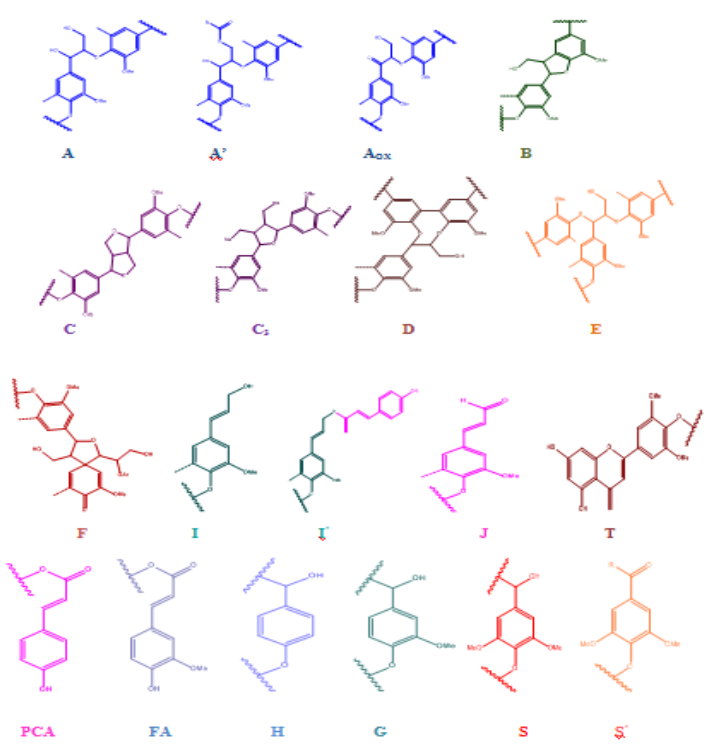

Fig. 4. Main structures present in lignins of sugarcane bagasse (Silva et al., 2011).

boos are evergreen perennial flowering plants and have been considered as most primitive grasses which are also present in abundant form. Bamboo has similar components to bagasse and scanty of work has been reported on bamboo acting as an adsorbent for industrial effluent. So this review work is based on adsorption of dye from industrial effluent using bagasse as well as bamboo. The used fiber bundles can further be used as fuel for boilers and filling material for seats of cars, buses, trains and so many.

Bagasse as an adsorbent: Sugarcane is a member of Gramineae (grasses) family with scientific name of Saccharum officianrum. A tropical grass native to Asia, sugarcane plants have been grown for over 4000 years. Sugarcane is native to the warm temperate to tropical regions of South Asia and Melanesia, and used for sugar production. Sugarcane plant is two to six meters (six to twenty feet) tall. It has stout fibrous stalks which are rich in the sugar sucrose. Sugarcane is a C4 plant with a high rate of photosynthesis (its rates lies around $150-200 \%$ above the average for other plants). It can be characterized by segmented stems, blade-like leaves and production by seeds. Sugarcane plant originated from New Guinea where it has been known since about $6000 \mathrm{BC}$ and then spread along human migration routes. Sugarcane is common in tropical and subtropical countries throughout the world. Brazil,

Table 1. Chemical composition of sugarcane bagasse reported by various authors (Karp et al., 2013).

\begin{tabular}{llll}
\hline Components & Soccol et al., 2011 & Rocha et al., 2011 & Bertoti et al., 2009 \\
\hline Cellulose (\%) & $32-44$ & 45.5 & $47.5-51.1$ \\
Hemicellulose (\%) & $27-32$ & 27 & $26.7-28.5$ \\
Lignin (\%) & $19-24$ & 21.1 & $20.2-20.8$ \\
Extractives (\%) & - & 4.6 & $0.8-3$ \\
Ashes (\%) & $4.5-9$ & 2.2 & other components include resin, soaps, \\
& & & sulphur, ash like substances \\
\hline \hline
\end{tabular}


Chemical composition of bamboo

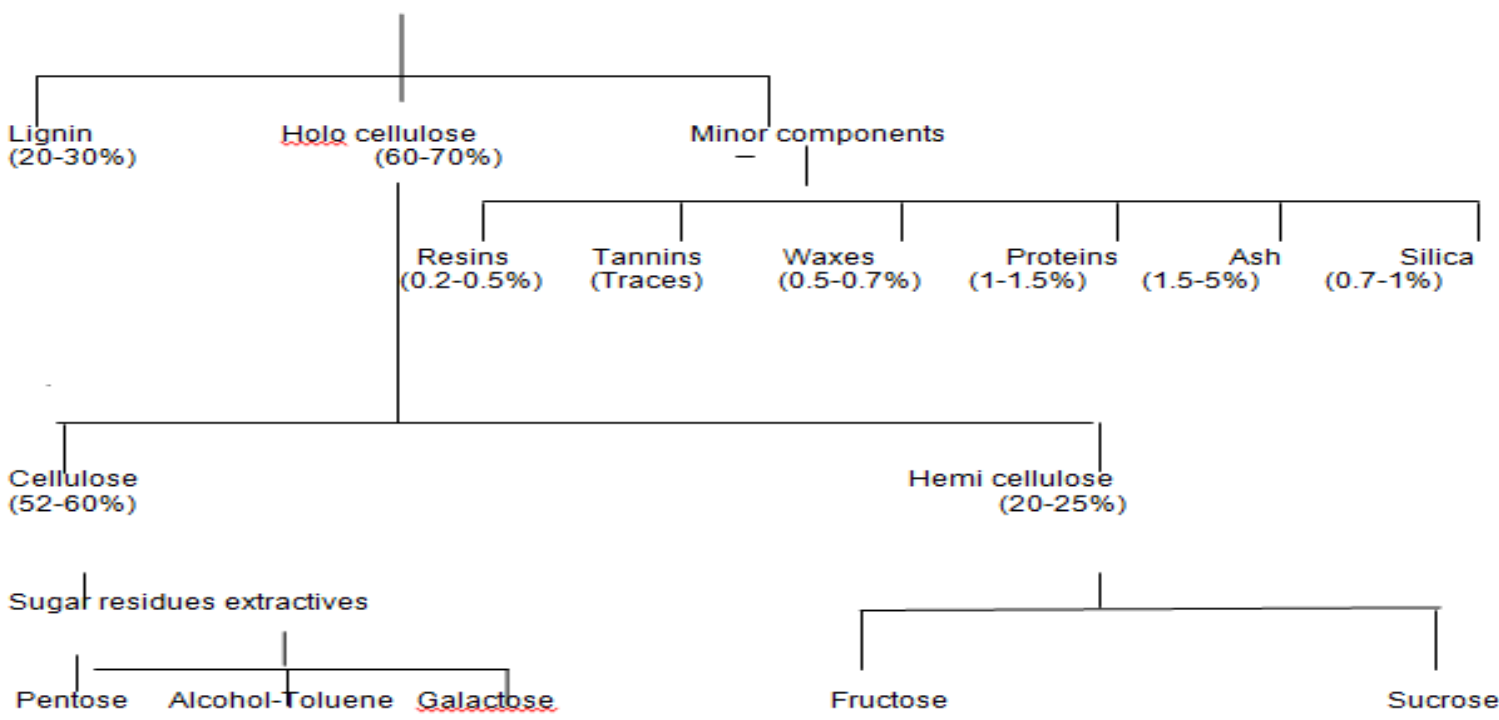

Fig. 5. Average chemical composition of bamboo (Lee et al., 1994).

Table 2. Some important tribes and sub-tribes of bamboo (Wilson and Loomis, 1964).

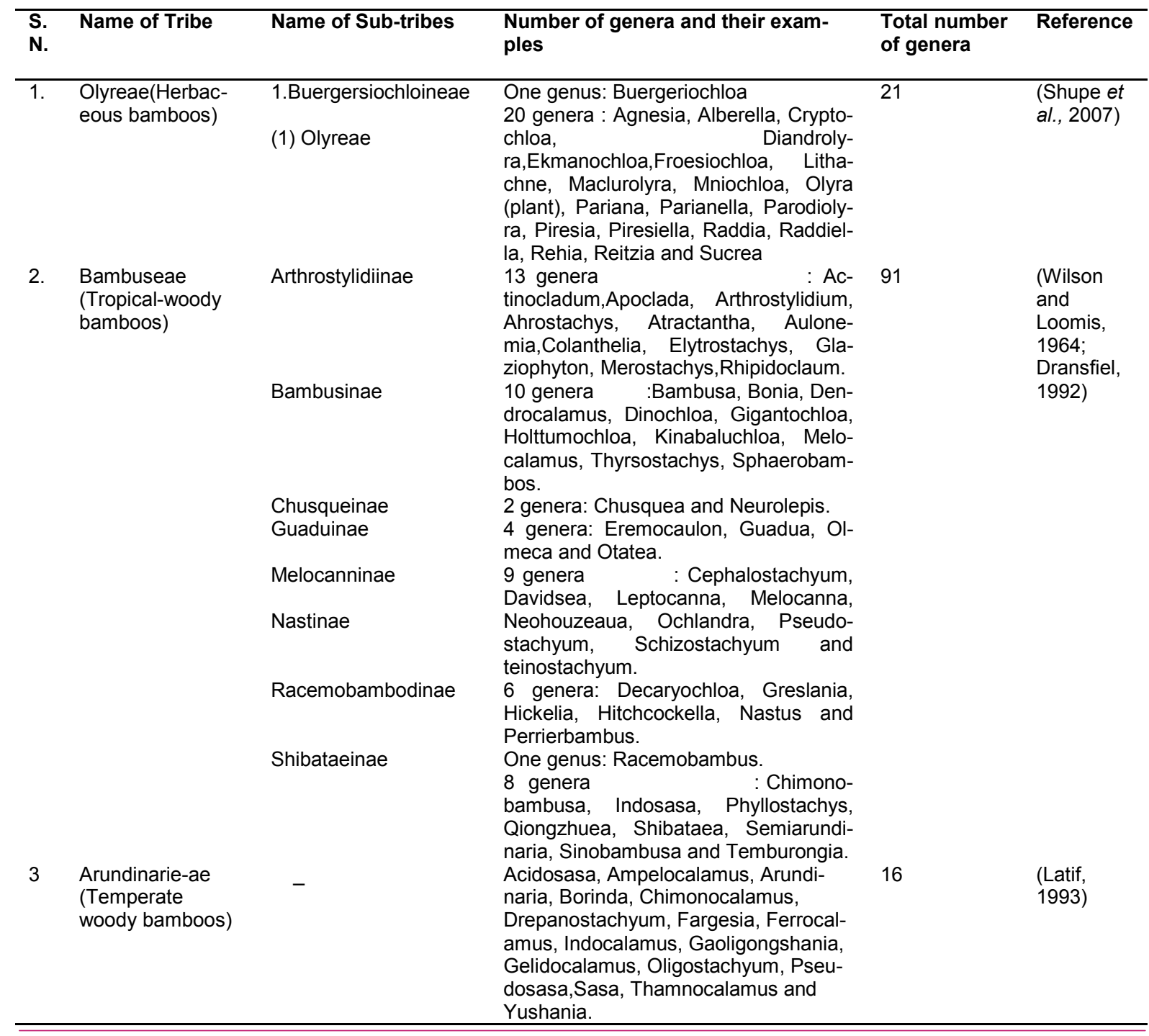


Table 3. Chemical analysis of various species of bamboo (Higuchi, 1957).

\begin{tabular}{lllllll}
\hline S.N. & Species & $\begin{array}{l}\text { Ash } \\
(\%)\end{array}$ & $\begin{array}{l}\text { Ethanol- toluene } \\
\text { extractives (\%) }\end{array}$ & $\begin{array}{l}\text { Lignin } \\
(\mathbf{\%})\end{array}$ & $\begin{array}{l}\text { Cellulose } \\
\text { (\%) }\end{array}$ & $\begin{array}{l}\text { Pentosan } \\
(\%)\end{array}$ \\
\hline 1. & Phyllostachys heterocycla & 1.3 & 4.6 & 26.10 & 49.10 & 27.70 \\
2. & Phyllostachys Nigra & 2.0 & 3.4 & 23.80 & 42.30 & 24.10 \\
3. & Phyllostachys Reticulata & 1.9 & 3.4 & 25.30 & 25.30 & 26.50 \\
\hline
\end{tabular}

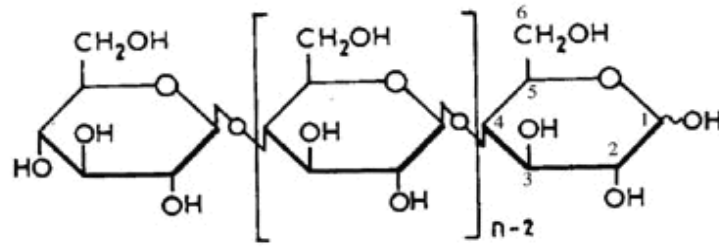

Fig. 6. Structure of cellulose (Ha et al., 1998).

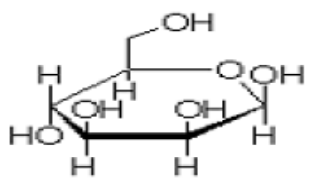

D-manose

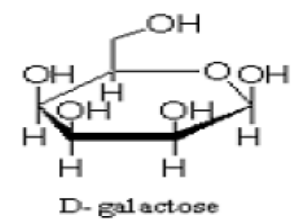

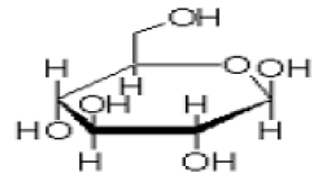

D- gly

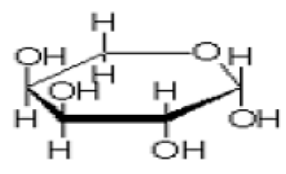

D-arabinose
Fig.7. Principal sugar residues of homocellulose (Sun, et al., 2012).

Philippine and China are three largest sugarcane plantation countries in the world (Pandey et al., 2000). It offers one of the most cost-effective renewable resources among those renewable energy options that are readily available in developing countries. Among the by-products available in the cane sugar extraction process, probably the most important one is bagasse (Silverstein et al., 2007). The main usage of sugarcane is to produce sugar, which can then be used in an infinite numbers of products. Sugarcane bagasse is a fibrous residue of cane stalks left over after the crushing and extraction of juice from sugarcane. Sugarcane bagasse has been utilized as a raw material for many processes and products which include electricity generation, paper production, products based on fermentation and in adsorption process (Pandey et al., 2000). It consists of water, fibers and trace amount of soluble solids. Table 1 shows the chemical composition of sugarcane bagasse which has been reported by various authors in a array of research papers (Bertoti et al., 2009; Rocha et al., 2011; Soccol et al., 2011; Karp, et al., 2013). It consists of lignin (20-30\%), cellulose (40

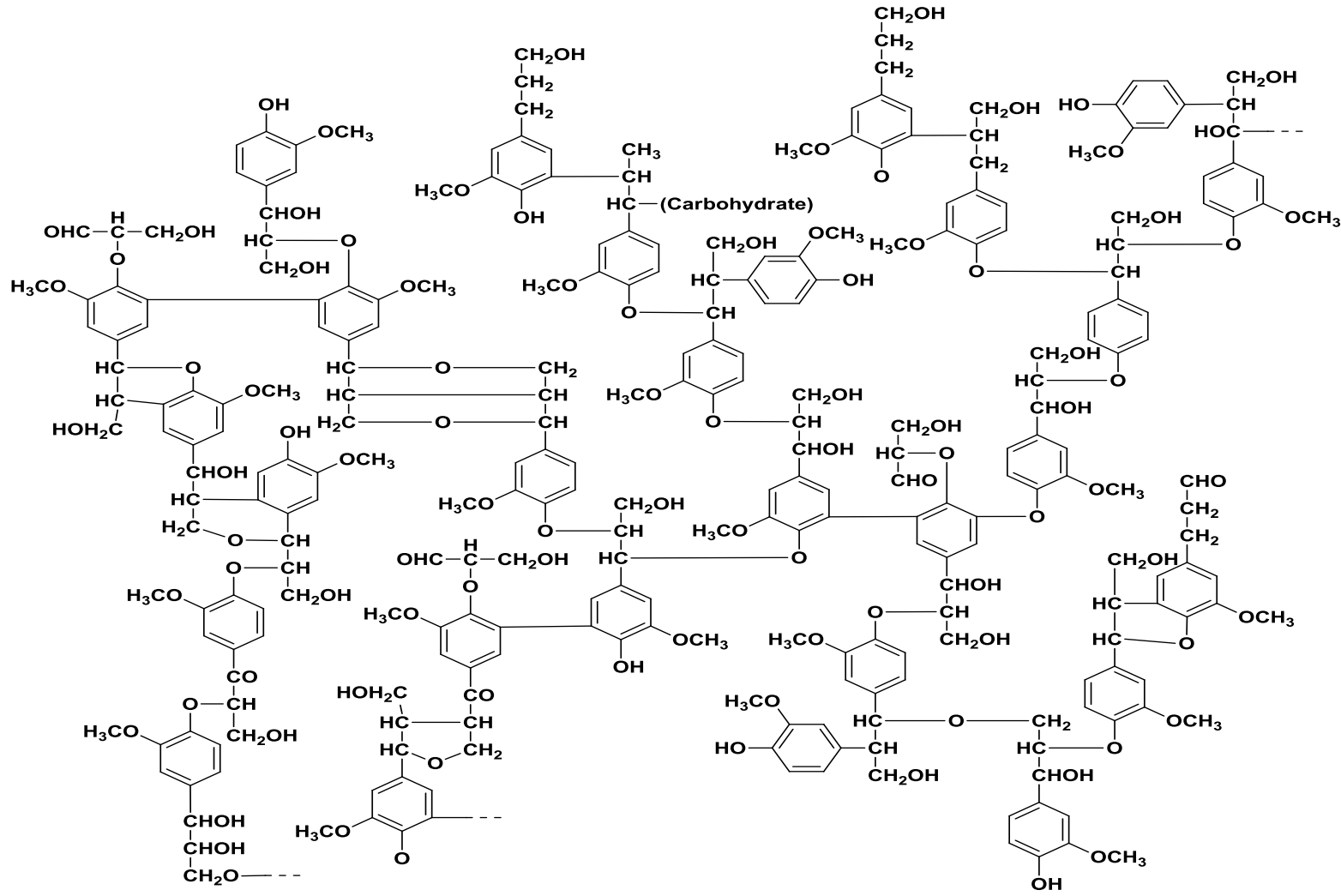

Fig. 8. Partial structure of one type of lignin (Campbell and Sederoff, 1996). 
Table 4. Effect of plant age on Chemical composition of bamboo (Zhao, 2007).

\begin{tabular}{lllllllll}
\hline $\begin{array}{l}\text { S. } \\
\text { N. }\end{array}$ & $\begin{array}{l}\text { Age Time } \\
\text { (years) }\end{array}$ & $\begin{array}{l}\text { Posi- } \\
\text { tion }\end{array}$ & $\begin{array}{l}\text { Ash } \\
(\%)\end{array}$ & $\begin{array}{l}\text { Hot-Water } \\
\text { Solubles(\%) }\end{array}$ & $\begin{array}{l}\text { Alcohol-toluene } \\
\text { soluble (\%) }\end{array}$ & $\begin{array}{l}\text { Lignin } \\
(\%)\end{array}$ & $\begin{array}{l}\text { Holo- } \\
\text { cellulose(\%) }\end{array}$ & $\begin{array}{l}\text { Alpha- } \\
\text { cellulose(\%) }\end{array}$ \\
\hline 1. & One & Bottom & 1.82 & 5.83 & 3.32 & 21.98 & 68.92 & 46.52 \\
& & Middle & 1.94 & 5.07 & 2.86 & 22.11 & 70.84 & 47.30 \\
& & Top & 1.95 & 5.14 & 3.48 & 21.26 & 71.95 & 47.51 \\
2. & Three & Bottom & 1.30 & 6.33 & 4.17 & 23.21 & 68.58 & 46.21 \\
& & Middle & 1.36 & 6.91 & 4.38 & 23.95 & 72.69 & 46.82 \\
& & Top & 1.41 & 7.43 & 5.21 & 23.71 & 73.82 & 47.51 \\
3. Five & Bottom & 1.26 & 4.89 & 6.61 & 22.93 & 69.94 & 46.08 \\
& & Middle & 1.30 & 5.19 & 6.81 & 22.97 & 72.50 & 47.65 \\
& & Top & 1.35 & 5.84 & 7.34 & 23.02 & 73.65 & 47.91 \\
\hline
\end{tabular}

$-45 \%$ ) and hemicelluloses (30-35\%) (Peng et al.,2009). As bagasse is a waste product in sugar industry which acquires additional disposal cost, therefore, most of the mills use it in the boiler as fuel for steam production. The surplus of the bagasse is used in the industry to produce paper, ethanol and livestock feed and building materials. In addition, it can be used for production of important enzymes such as cellulase, xylanase, am-<smiles>CCCc1ccccc1</smiles>

Phenylpropane coniferyl alcohol<smiles>COc1cc(/C=C/CO)cc(OC)c1O</smiles>

sinapyl alcohol

Fig.9. Building blocks of lignin (Lee, 1996).

ylase, inulinase and lipase (Paturau, 1989).

Cellulose in bagasse: Cellulose occurs as the major constituent of all plant materials and forms about half to one-third of plant tissues. It is constantly replenished by photosynthesis, with estimates of annual world biosynthesis of 1011 tons. In particular, cellulose is the main constituent of higher plants, including wood, cotton, flax, hemp, jute, SCB, ramie, cereal straws, etc. (Sun et al., 2004). Cellulose is a crystalline, high molecular weight linear homopolymer of repeated units of cellobiose where two anhydrous glucose rings linked by a $\beta-1,4$ glycosidic chains. It is completed via the occurrence of 3 hydroxyl groups through different acidity/reactivity, secondary $-\mathrm{OH}$ at the C2 , secondary $-\mathrm{OH}$ at the $\mathrm{C}-3$, and primary $-\mathrm{OH}$ at the C-6 position. Therefore, different intermolecular and intramolecular hydrogen bonds help to

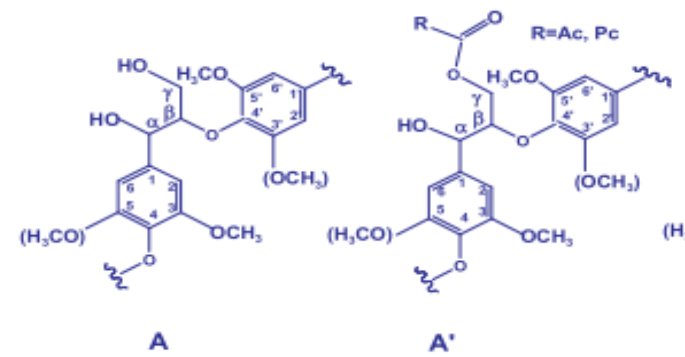

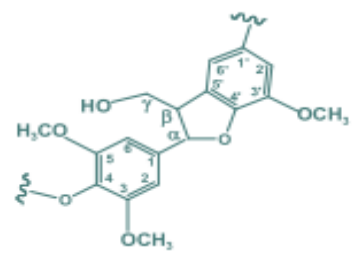

C

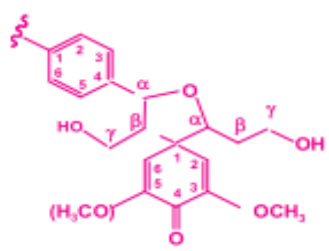

D

$\mathrm{S}$

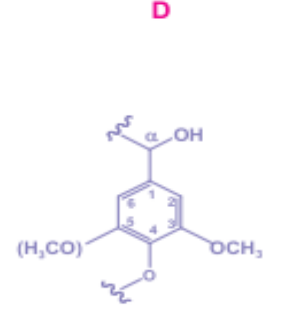

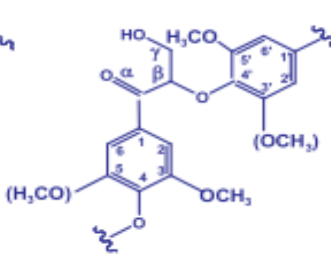

A*

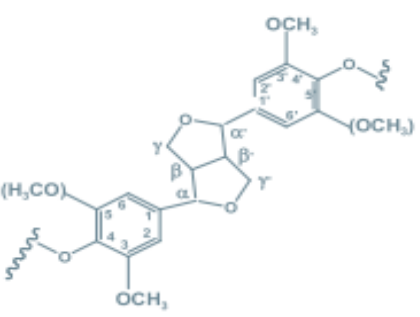

B

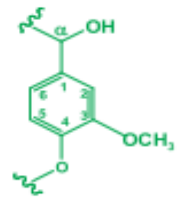

G
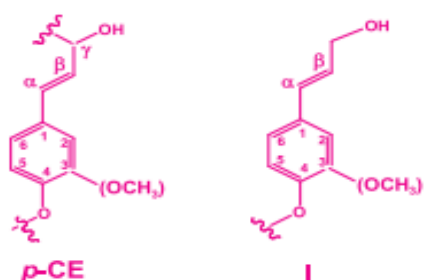

I

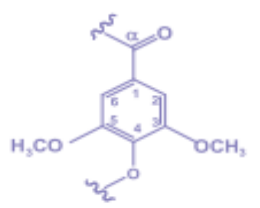

$S^{\prime}$

Fig. 10. Main substructures of lignin in bamboo (Zhangav et al., 2017). 


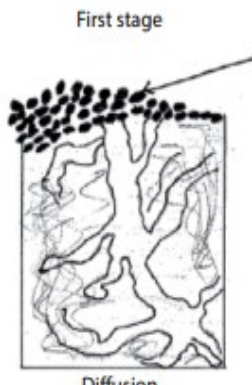

Diffusion

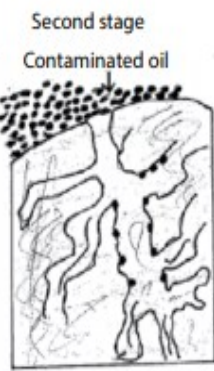

Migration

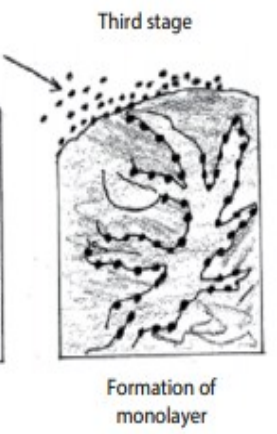

monolayer
Fig. 11. Schematic mechanism of the adsorbate disperses from the main body of waterway (Chattopadhyay and Kaur, 2017).

retain ribbon- like straight formation (Saheb and Jog, 1999). Cellulose possesses equally amorphous as well as crystalline arrangement. The variation in degree of crystallinity of the cellulose depends on its species. This is produced by polymerization of $\mathrm{D}$-anhydroglucopyanose units through 1, 4 -glycosidic linkage. The high degree of polymerization and linear orientation are responsible for the stiffness in the plant. The structural formula of cellulose is shown in Fig. 2.

Hemi-cellulose in bagasse: Larabinose, Dgalactose, D-glucose, D-mannose and D-xylose as well as other components such as acetic, glucuronic and ferulic acids are five common sugars of hemicelluloses. It is a linear and branched heterogeneous polymer (Fig. 3). The basic structure of this polymer is similar to cellulose but comprising shorter chain length. Pentosan and a little hexosan are also present in its structure (Klemm et al., 1999). Hemicelluloses presenting the cell wall

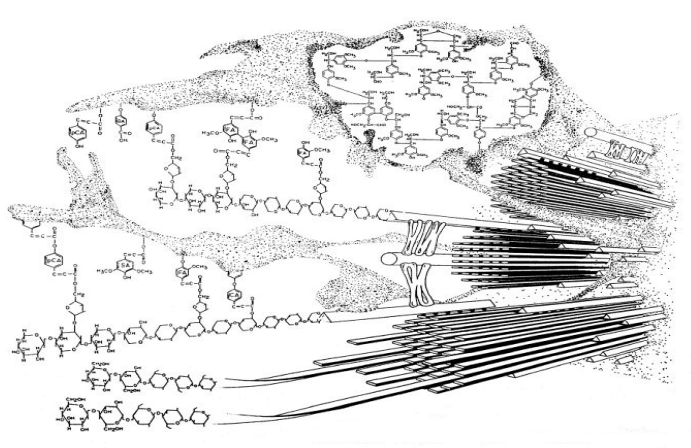

Fig. 12. Secondary Cell-Wall(CW) Structure of cellulose, hemicellulose, and lignin in lignocellulosic materials (Bidlack et al., 1992).

of plant are heteropolysaccharides. On the other side, Xylans are the mainly rich of the hemicelluloses exist in the cell walls of land plants, of which they can comprise additional mass i.e. $30 \%$ of the dry weight (Sun, et al., 2004). Cellulose and homocelluloses can be differentiated by composition of sugar parts, by existence of smaller chains, by a division of major chain molecules, and to be amorphous which insist its structure easier to hydrolyze than cellulose (Fengel and Wegener, 1989).

Lignin in bagasse: Lignin is a very complex aromatic molecule raised by the grouping of phenylpropane components allied in a large 3D structure. Three main phenyl propionicalcohols present as monolignils of lignin: p-coumaryl alcohol, coniferyl alcohol and sinapyl alcohol. Lignin and a few of its consequences, bent through the exclusion of lignin from biomass, may slow down the enzymes that accomplish the fermentation proce-

Table 5. Traditional and Non-traditional Uses of Bamboo (Casin and Mosterio, 1970).

\begin{tabular}{l}
\hline As a plant \\
\hline Ecology \\
Hedges and screen \\
Minimal land use \\
Uses on marginal land
\end{tabular}

Agro-forestry

Natural strands

Plantations

Mixed agro-forestry systems

Animal diet (Main food of giant panda)

Food ingredient

Pickled bamboo shoots cooked with black eyed beans as a delicacy food in Nepal

Used in pancakes

Various culinary preparations (amil- a sour vegetable soup)

Chinese medicine for treating infections and healing
As a material

Local industries

Artisans

A variety of utensils

Furniture

Construction material

Fishing and aquature applications

Textiles

As a writing surface

Used as staves which is used in the Indian material art of Gatka

Crafting bows

Musical instruments

Wood and paper industries

Strand boards

Laminated lumber

Medium density fibreboard

Paper and rayon

Energy

Charcoal

Pyrolysis 
Table 6. Classification of dyes (Basava Rao and Mohan Rao, 2006).

\begin{tabular}{|c|c|c|c|}
\hline Dye Class & $\begin{array}{l}\text { Principal textile sub- } \\
\text { strates }\end{array}$ & Method of application & $\begin{array}{l}\text { Chemical Types present in } \\
\text { dyes }\end{array}$ \\
\hline Acid & $\begin{array}{l}\text { Nylon, wool, silk, paper, } \\
\text { inks and leather }\end{array}$ & $\begin{array}{l}\text { Usually from neutral to acidic } \\
\text { dyebaths }\end{array}$ & $\begin{array}{l}\text { Azo (including } \\
\text { premetallised), } \\
\text { antraquinone, } \\
\text { triphenylmethane, } \\
\text { azine, xanthene, nitro and ni- } \\
\text { troso }\end{array}$ \\
\hline Basic & $\begin{array}{l}\text { Paper, } \\
\text { polyacrylonitrile, } \\
\text { modified nylon, polyester } \\
\text { and inks }\end{array}$ & Applied from acidic dyebaths & $\begin{array}{l}\text { Cyanine, hemicyanine, } \\
\text { diazahemicyanine, } \\
\text { diphenylmethane, } \\
\text { triarylmethane, azo, } \\
\text { azine, xanthene, acridine, oxa- } \\
\text { nine and anthraquinone }\end{array}$ \\
\hline Direct & $\begin{array}{l}\text { Cotton, rayon, paper, } \\
\text { leather and nylon }\end{array}$ & $\begin{array}{l}\text { Applied from neutral or slightly } \\
\text { alkaline baths containing addi- } \\
\text { tional electrolyte }\end{array}$ & $\begin{array}{l}\text { Azo, phthalocyanine, stilbene } \\
\text { and oxanine }\end{array}$ \\
\hline Disperse & $\begin{array}{l}\text { Polyester, polyamide, } \\
\text { acetate, acrylic and plas- } \\
\text { tics }\end{array}$ & $\begin{array}{l}\text { Fine aqueous dispersions often } \\
\text { applied by high temperature/ } \\
\text { pressure or lower temperature } \\
\text { carrier methods; dye may be } \\
\text { padded on cloth and baked on or } \\
\text { thermo fixed }\end{array}$ & $\begin{array}{l}\text { Azo, anthraquinone, } \\
\text { styryl, nitro and benzodi- } \\
\text { furanone }\end{array}$ \\
\hline Reactive & $\begin{array}{l}\text { Cotton, wool, silk and ny- } \\
\text { lon }\end{array}$ & $\begin{array}{l}\text { Reactive site on dye reacts with } \\
\text { functional group on fiber to bind } \\
\text { dye covalently under influence of } \\
\text { heat and pH (alkaline) }\end{array}$ & $\begin{array}{l}\text { Azo, anthraquinone, } \\
\text { phthalocyanine, formazan, } \\
\text { oxanine and basic }\end{array}$ \\
\hline Solvent & $\begin{array}{l}\text { Plastics, gasoline, } \\
\text { varnishes lacquers, } \\
\text { stains, inks, fats, oils and } \\
\text { waxes }\end{array}$ & Dissolution in the substrate & $\begin{array}{l}\text { Azo, triphenylmethane, } \\
\text { anthraquinone and phthalocya- } \\
\text { nine }\end{array}$ \\
\hline Sulphur & Cotton and rayon & $\begin{array}{l}\text { Aromatic substrate vatted with } \\
\text { sodium sulphide and } \\
\text { reoxidised to insoluble } \\
\text { sulphur-containing products on } \\
\text { fiber }\end{array}$ & Indeterminate structures \\
\hline Vat & Cotton, rayon and wool & $\begin{array}{l}\text { Water-insoluble dyes } \\
\text { solubilised by reducing with sodi- } \\
\text { um hydrogensulphide, then ex- } \\
\text { hausted on fiber and reoxidised }\end{array}$ & $\begin{array}{l}\text { Anthraquinone } \\
\text { (including polycyclic } \\
\text { quinines) and indigoids }\end{array}$ \\
\hline
\end{tabular}

dure, declining biofuel acquiesce (Bottcher et al., 2017). The variation of lignin composition can also exist because of different taxa and even though among diverse tissues as well as cell-wall coatings as of the same plant. The key structures of lignin present in the sugarcane bagasse are shown in Fig. 4. (Silva et al., 2011).

The molecular weight of lignin varies from 300 to $1,40,000$ depending on the source and the method of estimation (Gralen, 1946). In other words it can be concluded that it is a nonlinear polymer formed with different monomer units associated by chemically assorted and little-reactive bonds prevents the aptitude of any single enzyme to correctly identify to degrade it. Alcoholic and phenolic hydroxyl groups are most reactive groups in it. Lignin is formed by oxidative polymerization of phenyl propane units to provide bulky cross-linked molecules holding carbon-carbon and ether linkages. Sugarcane contains a prevalence of $p$ coumaric alcohol which facilitates to a higher con- centration of p-hydroxyphenyl alcohol (Del Río et al., 2015).

Uses of sugarcane bagasse: Sugarcane bagasse is a cheap waste material left in the sugar industries that incurs additional disposal cost. The excess of the bagasse is used in the industry to produce ethanol, paper, building materials and livestock feed. In addition, it can also be used to produce various important enzymes such as cellulase, xylanase, amylase, inulinase and lipase (Singh et al., 2009). Bagasse is used as a primary fuel for sugar mills. In various tropical countries, it is the major agricultural crop which is cultivated in abounded form. Sugarcane residues viz. sugarcane bagasse and its leaves have been investigated for biotechnological and nonbiotechnological applications point of view. Apart from these, sugarcane bagasse and sugarcane leaves have also been surveyed for employ in lignocellulosic bioconversion, which leads to the economic utilization of residual substances in the 
production of bioethanol as well as value-added commercial products like xylitol, enzymes, organic acids, single-cell protein, etc. (Chandel et al., 2012).

Bamboo as an adsorbent: Bamboo is a kind of grass with a firm, woody and empty stem. It is a recurrent evergreen, which means it grows every year and stays green year around due to a rare rhizome dependent system. The scientific name of bamboo is Bambusoideae. It covers 1250 species within 75 genera, most of which are relatively fastgrowing, achieving maturity within five years, but flowering uncommonly. This composite material can be grown in abundance in most of the hot countries. It is known as a composite material as it consists of cellulose fibers which are surrounded by lignin matrix. Other organic components are also present in addition to cellulose and lignin. It contains about $2-6 \%$ starch, $2 \%$ deoxidized saccharide, $2-4 \%$ fat and $0.8-6 \%$ protein (Scurlock et al., 2000). The main properties of the bamboo culm are resolute because of its anatomical structure. Its culm consists of internodes as well as nodes. In the internodes the cells are axially adjusted, while the nodes afford the transversal interconnections (Lessard and Chouinard, 1980). Bamboo is inexpensive, fast-growing, and easily available, having comparable physical and mechanical properties to wood and can be processed by existing technologies. The fast growth characteristic of bamboo is an advantage for its utilization. Its ecological functions like soil and water conservation alongwith erosion control are remarkable. On the behalf of Morphology of structure, bamboo species can be classified as either monopodial or sympodial ones and dissimilarities in rhizome system can be observed based on adaptations to the climatic conditions (Gratani et al., 2008). The bamboo contains three clades classified as tribes (Wilson and Loomis, 1964).

Chemical composition of bamboo: Bamboo fibre is composed of a-cellulose, hemi-cellulose and lignin along with some minor constituents. The average chemical composition of bamboo is presented in Fig. 5.

The chemical composition of bamboo is almost same to that of wood. Consequently the main constituents of bamboo culms are cellulose $(52-60 \%)$, hemi-cellulose (20-25\%) and lignin (20-30\%), which is $90 \%$ of the total mass. The negligible constituents of bamboo are resins, tannins, waxes $(0.5-0.7 \%)$ and some inorganic salts. Compared with wood bamboo is said to have higher alkaline extractives, ash and silica contents (Lee et al., 1994). Owing to the information that it is available in abundant form and economical, it should be used to its fullest level (Tewari, 1992). Alphacellulose, lignin, extractives, pentosan, ash and silica content amplified with growing age of bamboo (Yusoff, et al., 1992). Bamboo also contains other organic compounds viz. 2-6\% starch, $2 \%$ deoxidized saccharide, $2-4 \%$ fat, and $0.8-6 \%$ protein, in addition to cellulose as well as lignin. It is veru much durable because of the carbohydrate content of bamboo (Latif et al., 1991). Table 3 illustrates the analysis of bamboo depending on three different species (Higuchi, 1957). The properties of these bamboo species differ a lot and different species are suggested for different functions. Owing to this information, detection of bamboo species is essential before its efficient utilization. Table 4 shows the chemical composition of bamboo of different age groups (Zhao, 2007).

Cellulose in bamboo: It contains both amorphous and crystalline structure. The degree of crystallinity of the cellulose varies from species to species. It is formed by polymerization of $D$ anhydro glucopyanose units through $1,4 \beta$-glycosidic linkage and provides the stiffness to the plant due to its high degree of polymerization and linear orientation (Ha et al., 1998). The structural formula of cellulose is shown in Fig. 6. (Ha et al., 1998). The lengthy-chain cellulose polymers are connected together by hydrogen and vander Waals bonds, which cause the cellulose to be packed into microfibrils (Zhang and Lynd, 2004). By forming these hydrogen bounds, the chains tend to arrange in parallel and form a crystalline structure. Therefore, cellulose microfibrils have both highly crystalline regions (around 2/3 of the total cellulose) and less-ordered amorphous regions (Figure 1.5). More ordered or crystalline cellulose is less soluble and less degradable (Afrin et al., 2012). The degree of polymerization (DP) is defined as the number of glucose units in a cellulose molecules and cellulose possess good degree of crystallinity. Cellulose $\left(\mathrm{C}_{6} \mathrm{H}_{10} \mathrm{O}_{5}\right)_{\mathrm{n}}$ molecules are linear glucans having from $300,000 \mathrm{D}$ to $500,000 \mathrm{D}$ in molecular size. The degree of polymerization in plant/cane fibres like bamboo and bagasse is reported to be lowest (50-600) among the plant fibres depending upon the determination method used and according to one source it is 1050 of bleached bamboo (Dence, 1992).

Hemi-cellulose in bamboo: It is a polymer like cellulose but having shorter chain length (DP>150). It is composed of mainly pentosan and a little hexosan (Saheb and Jog, 1999). It is soluble in cold $18 \%$ caustic soda. The predominant polysaccharide in jute is composed of a backbone of $\beta-D$ - xylopyranose unit carrying a terminal 4-Omethyl - $\alpha-D-$ gulcouronic acid residue linked through position two. Hemicellulose is a linear and pronged heterogeneous polymer finished up of five diverse sugars - Larabinose, D-galactose, D-glucose, D-mannose, and D-xylose - in addition to other components such as acetic, glucuronic, and ferulic acids (Fig. 7). The vertebral column of the chains of hemicelluloses can be a homopoly- 
mer (usually consisting of single sugar replicate unit) or a heteropolymer (combination of dissimilar sugars). Consistent with the major sugar scum in the back, hemicellulose has diverse categorization viz., xylans, mannans, glucans, glucuronoxylans, arabinoxylans, glucomannans, galactomannans, galactoglucomannans, glucans, and xyloglucans (Sun et al., 2012). The bamboo xylan is considered in-between between hardwood and softwood xylans (Higuchi et al., 1966).

Lignin in bamboo: Lignin is a very complex molecule constructed of phenylpropane units linked in a large three-dimensional structure. Three phenyl propionicalcohols exist as monomers of lignin: pcoumaryl alcohol, coniferyl alcohol and sinapyl alcohol. Lignin is closely bound to cellulose and hemicellulose and its function is to provide rigidity and cohesion to the material cell wall, to confer water impermeability to xylem vessels, and to form a physio-chemical barrier against microbial attack (Fengel and Wegener, 1989). Lignin is mainly composed of phenylpropane or C9 units. Three different types of C9 units are present in lignin. The lignin present in bamboos is unique. The lignification process undergoes changes during the elongation of the culm, the full lignification of the bamboo culm is completed within one growing season, showing no further ageing effect. The length of fibres varies with the variation of lignin content in bamboo. The middle position has a long fibre. The outer and inner positions having short fibres possess higher lignin content. Lignin is often called the cementing agent that binds individual cells together (Campbell and Sederoff, 1996).

\section{Uses of bamboo}

Dyes as pollutants: Dyes and pigments are measured as one of the major toxins and it is affirmed as 'noticeable noxious waste'. When these dyes after the use, discharge into water sources, then these are not only influences their visual nature but obliterates marine life due to rich color, chemical oxygen demand (COD), high biochemical oxygen demand (BOD), total organic carbon (TOC) as well as perched solids. On the other side, unused and hydrolysed dyes may also harmful for living life forms such as dysfunction of brain, kidney, reproductive system, liver, and essential nervous structure. As a result, it is necessary to produce economical and efficient methods to solve the pollution troubles created by unused dye present in the effluent (Wei Low et al., 2012). There are many types of dyes like direct, reactive, vat, sulphur, acidic, basic, disperse (dyes for polyester), azo, diazo, anthroquinone based and metal complex dyes, generally used by textile industries. Most of these dyes are toxic, mutagenic and carcinogenic in nature and their deletion from industrial effluents before discharging into the surroundings is very much imperative (Hameed and El-
Khaiary, 2008). Effluents coming from textile industries are extremely toxic in nature as they contain a large number of metal complex dyes (e.g. $\mathrm{Cr}$ and Co complexes) along with the traces of various acids, alkalis and salts used during wet processing of textile substances. Number of smallscale dyeing industries is facing the problem of shutting since they are not treating their effluents. Also, it is not viable for them to treat the effluent using various existing methods. Hence, it is essential that an appropriate healing method should be invented (Basava Rao and Mohan Rao, 2006). Economical sorbents are the best option for these industries. Before adopting any kind of sorbent, it is very much required to understand the different dyes and their usages according to the application point of view. The classification dyes according their usage is shown in Table. 6.

Adsorption of dye: Adsorption is a trend in which gas or liquid fragments get adhered on the exterior of porous material. It is a surface phenomenon and the fluid molecule which gets adsorbed is known as adsorbate. The porous solid material on which the adsorbate gets adsorbed is called adsorbent. This method of adsorption consists of severance of a material from one stage accompanied by its accretion or concentration at the surface of another. The accurate character of the bonding depends on the particulars of the genus involved, however the adsorbed substance is normally categorized as showing physic-sorption or chemi-sorption. It has also been reported that an adsorbent is stuff, typically porous in nature along with high surface area that can absorb substances onto its surface by intermolecular forces (Chincholi et al., 2014).

It has been concluded from literature survey that the sugarcane bagasse is composed around of $40 \%$ cellulose, $24 \%$ hemicellulose, and $25 \%$ lignin. On the other side, Bamboo is composed of cellulose (45-55\%), hemi-cellulose (20-25\%) and lignin $(22-30 \%)$. In plant cells, including sugarcane and bamboo plants, a secondary wall, consisting of three layers (S1, S2 and S3) which is bounded by a thin primary wall. The secondary wall is surrounded by lignin component. Amorphous cellulose and hemicellulose have been contained by S1 and S3 layers. Out of these two, this amorphous milieu is highly responsible for attracting the hydrolysed as well as unused dye in the effluent. However, the S2 layer contains crystalline cellulose and these crystalline areas are formed in a extremely ordered way by linear forms of hydrogen bonds which enhance the wicking prosperity of aqueous solutions in this particular cell wall. Though amorphous regions also exist in the cellulose and amorphous cellulose, hemicellulose, along with lignin are also present between the layers (S1, S2 and S3) (Fox et al., 1987). An illustration of the structure of the cell wall with its 
component organization is shown in Figure 12 (Bidlack et al., 1992).

Different pretreatments are generally given to the lignocellulosic fibers for effective adsorption. It can be observed that there is change in the cellulose, hemicelluloses or lignin structure with pretreatment methods. Alkali treatment reduces the lignin and hemicellulose content in biomass, increases the surface area, allowing penetration of water molecules to the inner layers, and breaks the bonds between hemicellulose and lignincarbohydrate (Gratzl and Chen, 1999). Reacting biomass with dilute sulfuric acid alters the crystalline nature of the cellulose structure by expanding the surface area of the biomass, allowing water penetration into the crystalline structure. Dilute sulfuric acid treatment improves ease of solubilization of biomass and formation of glucose (Ingram and Doran, 1995). Concentrated sulfuric acid pretreatment solubilizes cellulose by breaking down the hydrogen bonds in hemicelluloses and partially degrades cellulose as well as lignin. Cellulose can be degraded to glucose by acid. The cellulose molecule is characterized by $\beta-1,4-$ glucosidic linkages between sequential glucose units. There are three reactive hydroxyl groups in each glucose unit (Camacho et al., 1996). Acid can attack the $\beta-1,4$-glucosidic linkages in cellulose leading to degradation. Pretreatment is an important tool for practical cellulose conversion processes, and is the subject of this article. Pretreatment is required to alter the structure of cellulosic biomass to make cellulose more accessible to the enzymes that convert the carbohydrate polymers into fermentable sugars as represented in the schematic diagram of Figure 1.12. The goal is to break the lignin seal and disrupt the crystalline structure of cellulose (Mosier et al., 2005).

Observations drawn: The present study revealed that although some reports are available on the use of bagasse as a sorbent for number of dyes viz. Rhodamine B (RhB), Basic Blue 9 (BB9, also known as methylene blue) etc., but yet reports concerning the use of bamboo are scanty. Natural bamboo fibers possess good potential and may be used as sorbents in textile industries. The high lignin content of the fibre is the major cause of its stiffness. The bamboo is highly renewable grass and can be classified as ecofriendly. Thus, keeping in view of these observations, in the present investigation, it has been suggested to design agricultural based sorbents using bagasse and extracted bamboo fibres from raw culm for textile effluent treatment.

Conclusions and future perspectives: Adsorption is an attractive and effective method for dye removal from wastewater, especially if the adsorbent is cheap and widely available. In this review, uses of bagasse and bamboo for the adsorption of unused as well as hydrolysed dyes from effluent water may be used based on a significant number of relevant published editorials. The use of bagasse and bamboo as a biosorbents for removing various types of dyes from effluent water offers many attractive features such as the outstanding adsorption capacity and the fact that these materials are low-cost, non-toxic and biocompatible. There is a particular need for future studies to verify the performance of the bagasse and bamboo as low-cost adsorbents at the pilot plant scale. There is a great need for additional research concerning as to how to further process or dispose off bagasse and bamboo fibre bundles after their use for the removal of dyes.

\section{REFERENCES}

1. Abd, Latif M. (1993). Effects of age and height of three bamboo species on their machining properties. Journal Tropical Forest Science. 5(4): 528- 535.

2. Abd, Latif M., Nor Azah, M.A. and Khoo, K.C., (1991). Carbohydrates in some natural stand bamboos. Journal Tropical Forest Science. 4 (4): 310- 316.

3. Afrin, T., Tsuzuki, T., Kanwar, R.K. and Wang, X. (2012). The origin of the antibacterial property of Bamboo. J. Text. I. 103(8): 844-849.

4. Azhar, S. S., Liew, A. G., Suhardy, D., Farizul Hafiz, K. and Irfan Hatim M.D. (2005). Dye removal from aqueous solution by using adsorption on treated sugarcane bagasse. Am J Appl Sci. 2: 1-5.

5. Basava Rao, V.V. and Mohan Rao, S.R. (2006). Adsorption studies on treatment of textile dyeing industrial effluent by flyash. Chem Eng J. 116: 77-84.

6. Bertoti, A.R., Luporini, S. and Esperidião, M.C.A. (2009). Effects of acetylation in vapor phase and mercerization on the properties of sugarcane fibers. Carbohyd Polym. 77: 20-24.

7. Bidlack, J., Malone, M. and Benson, R. (1992). Molecular Structure and Component Integration of Secondary Cell Walls in Plants. 72: 51-56.

8. Bottcher, A., Cesarino, I., Santos, A.B.D., Vicentini, R., Mayer, J.L.S, Vanholme, R., Morreel, K., Goeminne, G., Moura, J.C.M, Nobile, P.M, CarmelloGuerreiro, S.M. , dos Anjos, S. Creste, I.A., Boerjan, W., de Andrade Landell, M. G and Mazzafera P. (2013). Lignification in Sugarcane: Biochemical Characterization, Gene Discovery, and Expression Analysis in Two Genotypes Contrasting for Lignin Content. Plant Physiol. 163: 1539- 1557.

9. Brienzo, M., Carvalho, A. F. A, Figueiredo, F. C. de. and Neto, P. de. O. ( 2016). Sugarcane Bagasse Hemicellulose Properties, Extraction Technologies And Xylooligosaccharides Production. In book: Food Waste, Chapter 8, Nova Science Publishers, 155188.

10.Camacho, F., Gonzalez-Tello, P., Jurado, E., Robles, A. (1996). Microcrystalline-Cellulose Hydrolysis with Concentrated Sulphuric Acid. J. Chem. Tech. Biotechnol. 67: 350-356.

11.Campbell, M., Sederoff, R. (1996). Variation in lignin content and composition. Mechanisms of control and implications for the genetic improvement of plants. Plant. Physiol. 110: 3-13.

12.Casin, R. F., Mosterio, A. D. (1970). Utilization and prevention of bamboos, Furriddecom word Preservation Report. 5(6): 82- 88. 
13.Chandel, A. K., da Silva, S. S., Carvalho, W., Singh and Om. V. (2012). Sugarcane bagasse and leaves: foreseeable biomass of biofuel and bio-products. Journal Chem Technol Biotechno. 87: 11-20.

14.Chincholi, M., Sagwekar, P., Nagaria, C., Kulkarni, S. and Dhokpande, S. (2014). Dye removal by Adsorption using waste biomass: Sugarcane Bagasse. IJETTS. 01: 552-559.

15.Cisneros, R.L., Espinoza, A.G., Litter, M.I. (2002). Photodegradation of an azo dye of the textile industry. Chemosphere. 48: 393-399.

16.Da Silva, L.G., Ruggieroa, R., Gontijoa, P.M., Pintob, R.B., Royerb, B., Limab, E.C., Fernandesb, T. H.M. and Calvete ,T. (2011).Adsorption of Brilliant Red 2BE dye from water solutions by a chemically modified sugarcane bagasse lignin. Chem Eng J. 168: $620-628$

17.Del Río, J.C., Lino ,A. G., Colodette, J. L. , Lima, C. F., Errez, A.G., Martínez, A.T., Lu, F., Ralph, J. and Rencoret , J. (2015). Differences in the chemical structure of the lignins from sugarcane bagasse and straw. Biomass And Bioenergy. 81: 322-338.

18.Dence, C. W. (1992). The determination of Lignin, In S. Y. Lin and C. W. Dence (Eds.), Methods in Lignin chemistry, Chapter 3, Berlin: Springer-Verlag. 33- 61.

19.Dransfield, S. (1992). The bamboos of Sabah. Herbarium, Royal Botanic Garden. Kew, U.K. in association with Herbarium, Forest Research Centre. Sabah, Malaysia: Forestry dept. 1992, Records, No.14.

20.Fengel, D., Wegener, G. (1989). Wood: Chemistry, ultrastructure, reactions. Walter De Gruyter, New York.

21.Fox, D. J., Gray, P. P., Dunn, N. W., Marsden, W. L. (1987). Factors Affecting the Enzymic Susceptibility of Alkali and Acid Pretreated Sugar-cane Bagasse. $J$ Chem Technol Biotechnol. 40: 117-132.

22.Gähr, F., Hermanutz, F. and Oppermann, W. (1994). Ozonation- An important technique to comply with new German laws for Textile Wastewater Treatment. Wat. Sci.Tech. 30: 255-263.

23.Garg, V.K., Amita, M., Kumar, R. and Gupta, R. (2004). Basic dye (methylene blue) removal from simulated wastewater by adsorption using Indian Rosewood sawdust: a timber industry waste. Dyes Pigments. 63: 243-250.

24.Gralen, N. (1946). The molecular weight of Lignin. Journal of Colloid Science. 1(5): 453- 463.

25.Gratani, L., Crescente, M. F., Varone, L., Fabrini, G. and Digiulio, E. (2008). Growth pattern and photosynthetic activity of different bamboo species growing in the Botanical Garden of Rome. Flora 203: 77-84.

26.Gratzl, J.S. and Chen, C. (1999). Chemistry of Pulping: Lignin Reactions. ACS Symposium Series. Volume 742. Chapter 20: 392-421.

27.Ha, M.A., Apperley, D.C., Evans, B.W., Huxham, I.M., Jardine, W.G., Vietor, R.J., Reis, D., Vian, B. and Jarvis, M.C. (1998). Fine structure in cellulose microfibrils. NMR evidence from onion and quince. The Plant J. 16: 183- 190.

28. Hameed, B.H., Din, A.T.M. and Ahmad, A.L. (2007). Adsorption of methylene blue onto bamboo-based activated carbon: Kinetics and equilibrium studies. $J$ Hazard Mater. 141: 819-825.

29. Hameed, B.H. and El-Khaiary, M.I. (2008). Removal of basic dye from aqueous medium using a novel agricultural waste material: Pumpkin seed hull. J. Hazard. Mater. 155: 601-609.
30.Han, Y.W., Catalano, E. A. and Ciegler, A. (1983) Chemical and Physical properties of Sugarcane bagasse irradiated with y rays. J. Agric. Food Chem. 31: 34-38.

31.Higuchi, T. (1957). Biochemical studies of lignin formation, III. Physiol Plant. 10: 633- 648.

32. Higuchi, T., Kimura, N. and Kawamura, I. (1966). Differences of Chemical Properties of Lignins of Vascular Bundles and of Parenchyma Cells of Bamboos. Mokuzai Gakhaishi. 12: 173-177.

33. Hosono, M., Arai, H., Aizawa, M., Yamamot,I., Shimizu, K. and Sugiyama, M. (1993). Decoloration and Degradation of Azo Dye in Aqueous Solution Supersaturated with Oxygen by Irradiation of High-energy Electron Beams. Appl. Radial. Ht. 44(9): 1199-1203.

34.Ingram, L.O. and Doran, J.B. (1995). Conversion of cellulosic materials to ethanol. Fems Microbiol Rev. 16: 215-241.

35.Karp, S. G., Woiciechowski, A. L., Soccol, V. Th. and Soccol, C. R. (2013). Pretreatment Strategies for Delignification of Sugarcane Bagasse: A Review. Braz. Arch. Biol. Technol. 56(4): 679-689.

36.Chattopadhyay, D. P. and Kaur, V. (2017). Oil Spill Cleanup by Textiles. Chapter 2, Volume 4 of "Handbook of Composite from Renewable Materials" being published by Wiley-Scrivener, pp 27- 41.

37.Klemm, D., Philipp, B., Heinze, T., Heinze, U. and Wagenknecht, W. (1999). Comprehensive cellulose chemistry. Fundamentals and Analytical Methods. Chichester Wiley Vch. Vol 1. Wiley- VCH, Weinheim.

38.Lee, S. (1996). Alternative fuels. Taylor \& Francis Publishers, Washington, DC (now: CTC Press, Taylor \& Francis Group, Boca Raton, Florida).

39.Lee, A.W.C., Xuesong, B. and Perry, N.P. (1994). Selected physical and mechanical properties of giant timber bamboo grown in South Carolina. FPJ. 44(9): 40- 46.

40.Lessard G., Chouinard, A. (1980). Bamboo research in Asia. Proc Worksh Singapore 28-30 May 1980. Int Dev Res Center; and the Int Un For Res Org, Vienna, pp 121-150.

41.Malik, P.K. (2003). Use of activated carbons prepared from sawdust and rice-husk for adsorption of acid dyes: a case study of Acid Yellow 36. Dyes Pigments. 56: 239-249.

42.McKay, G., Ramprasad, G and Pratapa Mowli, P. (1985). Equilibrium Studies for the adsorption of dyestuffs from aqueous solutions by low-cost material. 29(3): 273-284.

43.McMullan, G., Meehan, C., Conneely, A., Kirby, N., Robinson, T., Nigam, P., Banat, I. M., Marchant, R., Smyth, W. F. (2001). Microbial decolourisation and degradation of textile dyes. Appl Microbial Biotechnol. 56: 81-87.

44.Mishra, G., Tripathy, M. (1993). A critical review of the treatments for decolourization of textile effluent. Colourage. 40: 35-38.

45.Mosier, N., Wyman, C., Dale, B., Elander, R., Lee, Y.Y., Holtzapple, M. and Ladisch, M. (2005). Features of promising technologies for pretreatment of lignocellulosic biomass. Bioresour Technol. 96: 673686.

46.Namasivayam, C., Muniasamy, N., Gayatri, K., Rani, M. and Ranganathan, K. (1996). Removal of dyes from aqueous solutions by cellulosic waste orange peel. Bioresour Technol. 57: 37-43.

47.Namasivayam, C., Prabha, D. and Kumutha, M. 
(1998). Removal of Direct Red and Acid Brilliant Blue by adsorption on to Banana Pith. Bioresour Technol. 64: 77-79.

48.Namboodri, C.G. and Walsh, W.K. (1995). Decolorizing spent dye bath with hot peroxide. Am. Dyest. Rep. 84: 86- 95.

49.Pandey, A., Soccol, C., Nigam, R. P. and Soccol, V. T. (2000). Biotechnological potential of agroindustrial residues. I: sugarcane bagasse., Bioresour Technol. 74: 69-80.

50.Paturau, J.M. (1989). By- Products of the cane sugar industry. An introduction to their industrial utilization. Elsevier Science Publishers B.V.

51.Peng, F., Ren, J.L., Xu, F., Bian, J., Peng, P., Cang Sun, R. (2009). Comparative study of hemicelluloses obtained by graded ethanol precipitation from sugarcane bagasse. J Agric Food Chem, 57: 6305-6317.

52.Rocha, G.J.M, Martin C., Soares, I.B., Souto-Maior, A.M, Baudel, H.M. and Moraes C.A. (2011). Dilute mixed-acid pretreatment of sugarcane bagasse for the ethanol production. Biomass Bioenerg. 35: 663670.

53.Saad, S.A, Isa, K.Md and Bahari, R. (2010). Chemically modified sugarcane bagasse as a potentially low-cost biosorbent for dye removal. Desalination. 264: 123-128.

54.Saheb, D. N. and Jog, J. P. (1999). Natural Fiber Polymer Composites: A Review. Ad. Polym. Tech. 18: 351-363.

55.Santhy, K. and Selvapathy, P. (2006). Removal of reactive dyes from wastewater by adsorption on coir pith activated carbon. Bioresour Technol. 97: 13291336.

56.Scurlock, J.M.O., Dayton, D.C., Hames, B. (2000). Bamboo: an overlooked biomass resource. Biomass And Bioenergy. 19: 229-244.

57.Sharma, N., Kaur, K., Kaur, S. (2009). Kinetic and equilibrium studies on the removal of $\mathrm{Cd}^{2+}$ ions from water using polyacrylamide grafted rice (Oryza sativa) husk and (Tectona grandis) saw dust. Journal Of Hazardous Materials. 163: 1338-1344.

58.Shupe, X.B., Peter, T.F., HSF, G. F, C. Y., Eberhardt, T.L. (2007). Chemical changes with maturation of the bamboo species. JTFS. 19(1): 6- 12.

59.Silverstein, R.A., Chen, Y., Sharma-Shivappa, R. R., Boyette, M.D. and Osborne, J. (2007). A comparison of chemical pretreatment methods for improving saccharification of cotton stalk. Bioresour Technol. 98: 3000-3011.

60.Singh, P., Nigam, N. and Pandey, A. (2009). Biotechnology for Agro-industrial residues Utilisation. Utilisation of agro-residues. Publishing House. 1-463.

61.Slokar, Y.M. and Le Marechal, A.M. (1998). Methods of Decoloration of Textile Wastewaters. Dyes Pigments. 37(4): 335- 356.

62.Soccol, C.R., Vandenberghe, L.P.S, Medeiros, A.B.P, Karp, S.G., Buckeridge and Ramos, L.P. (2011). Bioethanol from lignocelluloses: status and perspectives in Brazil. Bioresour Techno. 101: 4820 4825.

63.Sun, J.X., Sun, X.F., Zhao, H., Su, Y.Q., Sun, R.C. (2004). Fractional extraction and structural characterization of sugarcane bagasse and hemicelluloses. Carbohydr Poly. 56: 195-204.

64.Sun, J.X., Sun, X.F., Zhao, H. and Sun, R.C. (2004). Isolation and characterization of cellulose from sugarcane bagasse. Polym. Degrad. Stab. 84: 331-339.

65.Sun, S.N., Yuan, T. Q., Li, M.F., Cao, X. F., XU, F. and Liu, Q. Y. (2012). Structural characterization of hemicelluloses from bamboo culms. Cell Chem Technol. 46: 165-176.

66. Tewari, D.N. (1992). A monograph on bamboo. Published by: International Book Distributors, Dehra Dun (India), 1-498

67.Wei Low, L., Tjoon, T.T., Morad, N. and Azahari, B. (2012). Studies on the adsorption of methylene blue dye from aqueous solution onto low-cost tartaric acid treated bagasse. Procedia Apcbee. 1: 103-109.

68.Wilson, C.L. and Loomis, W.E. (1964). Botany, Third edition, Publisher: Holt, Rinehart and Winston, New York, $573 \mathrm{pp}$.

69.Xing, Y. and Wang, G. (2009). Poly (methacrylic acid)-modified sugarcane bagasse for enhanced adsorption of cationic dye. Environ Technol. 30(6): 611-619.

70.Yusoff, M.N.M.,.Kadir, A. Abd. and Mohamed, A.B. (1992). Utilization of bamboo for pulp and medium density board. In Proceeding of the seminar towards the management, conservation, marketing and utilization of bamboos, Kuala Lumpur, FRIM: 196- 205.

71.Zeng, C., Sun, L.S., Li, F., Ong, Y. K. and Chung, T.S. (2014). Treatment of highly concentrated wastewater containing multiple synthetic dyes by a combined process of coagulation/flocculation and nanofiltration. J Memb Sci. 469: 306-315.

72.Zhang, Y.H.P. and Lynd, L.R. (2004). Toward an aggregated understanding of enzymatic hydrolysis of cellulose noncomplexed cellulose systems. Biotechnol Bioeng. 88: 797- 824.

73.Zhangav, Y., Hou, Q., Xu, W., Qin, M., Fu ,Y., Wang, Z., Willför, S and Xu, C. (2017). Revealing the structure of bamboo lignin obtained by formic acid delignification at different pressure levels. Ind Crops Prod. 108(1): 864- 871.

74.Zhao, Z. (2007). Bamboo fibre and its manufacture. US Patent Application No. 2007/0267, 159. 